\title{
DAMPAK CAREER PLATEAU TERHADAP JOB SATISFACTION KARYAWAN GERAI MINIMARKET DI PALEMBANG
}

\author{
Ega Leovani \\ Fakultas Bisnis dan Akuntansi, Universita Katolik Musi Charitas Palembang \\ e-mail: egaleovani@yahoo.com
}

\begin{abstract}
Abstrak
Berbagai hal dilakukan perusahaan untuk memberikan job satisfaction terhadap karyawannya, salah satunya adalah jenjang karir di perusahaan, namun tidak semua jabatan dapat menapaaki jenjang karir diperusahaan, ada beberapa jabatan yang mengalami career plateu. Penelitian ini bertujuan mengetahui dampak career plateau terhadap job satisfaction karyawan gerai minimarket di kota Palembang. Penelitian ini menggunakan variabel independen career plateau (X), serta Job Satisfaction (Y). Data yang digunakan dalam penelitian ini adalah data primer. Pengumpulan data dalam penelitian ini menggunakan metode kuesioner yang disebar kepada 150 orang karyawan gerai minimarket di kota Palembang dengan metode purposive sampling. Sedangkan analisis dilakukan dengan pengolahan data menggunakan SPSS 19.0 for windows. Hasil dari penelitian ini menunjukan variabel bebas career plateau (X) memberikan pengaruh terhadap Job Satisfaction (Y) karyawan gerai minimarket di Palembang.
\end{abstract}

Kata Kunci: career plateau, job satisfaction

\begin{abstract}
Various things are done by companies to provide job satisfaction to their employees, one of which is a career path in the company, but not all positions can reach career paths in the company, there are several positions that experience career plates. This study aims to determine the impact of career plateau on job satisfaction of minimarket outlet employees in the city of Palembang. This study uses the independent variable career plateau $(X)$, and Job Satisfaction (Y). The data used in this study are primary data. Data collection in this study used a questionnaire method distributed to 150 employees of minimarket outlets in the city of Palembang with a purposive sampling method. While the analysis is done by processing data using SPSS 19.0 for windows. The results of this study indicate that the independent variable career plateau $(X)$ has an influence on Job Satisfaction ( $Y$ ) employees of minimarket outlets in Palembang.
\end{abstract}

Keyword: career plateau, job satisfaction 


\section{PENDAHULUAN}

Revolusi Industri 4.0 membuat berbagai perubahan dalam lingkungan masyarakat Indonesia saat ini. Berbagai kemudahan dihadirkan untuk orang mendapatkan apa yang diinginkan seperti contohnya adalah berbelanja. Ketika sedang berada dimanapun sangat mudah untuk mendapatkan tempat berbelanja seperti misalnya minimarket, warung kelontong, bahkan supermarket. Konsep ritel di Indonesia terbagi menjadi 2 konsep yaitu konsep retail tradisional dan konsep retail modern. Konsep retail tradisional seperti pasar tradisional, toko kelontong, serta warung-warung yang dikelola oleh masyarakat secara swadaya yang melakukan transaksi jual beli barang dagangan dengan konsep tawar menawar, sedangkan konsep gerai minimarket modern lebih kepada sistem penjualan dan pelayanan yang lebih modern seperti swalayan dan minimarket yang lebih mengedepankan teknologi. Fenomena menjamurnya gerai-gerai retail kecil di pelosok wilayah Indonesia saat ini, dua pemain retail yang memiliki gerai kecil yakni Alfamart dan Indomaret mencatat pertumbuhan pendapatan dan mencetak laba. Pada tahun 2018, Alfamart Group mampu mencatat pendapatan Rp. 66,8 Triliun atau tumbuh 8,7\% dibandingkan tahun sebelumnya 61,4 triliun. Sementara itu, pendapatan Indomaret pada 2018 tercatat sebesar Tp. 70,4 Triliun. Angka ini tumbuh sebesar $11 \%$ atau lebih besar dibandingkan pesaing lainnya. Laba bersih indommaret juga melesat pada tahun 2018 dengan total Rp. 765 miliar.

Saat ini Indonesia masih bertahan di 10 besar dalam Global Retail Developmenr (GRDI) 2017 yang dirilis oleh lembaga konsultan A.T. keanney. Pada tahun 2017, pasar retail Indonesia berada diposisi 8 dari 30 negara berkembang diseluruh dunia. Dalam daftar GRDI 2017, Indonesia memperoleh skor 55.9 dari skor tertinggi 100 dan berada diposisi 8. Posisi ini turun dari yang sebelumnya pada posisi ke 5 .

Berdasarkan informasi yang dihimpun dari situs berita online RMOLSumsel yang diakses Sabtu, 14 Januari 2019, 12:20:00 Wib Fitriani Agustinda selaku wakil walikota Palembang menyebutkan bahwa saat ini jumlah gerai minimarket di Palembang telah mencapai lebih dari 400 gerai yang telah melebihi standar aturan yang ada yang ada yaitu 150 gerai. Hal ini menunjukan bahwa perkembangan toko ritel di kota palembang amat pesat. Seiring dengan bertumbuhnya toko ritel, menunjukan bahwa kebutuhan akan sumber daya manusia yang akan mengisi berbagai jabatan 
Published online in http://e-journal.uniflor.ac.id/index.php/analisis

kebutuhan di toko ritel tersebut semakin banyak. Indonesia termasuk kedalam 10 besar negara yang memiliki pasar retail teraktif di dunia, hal ini tercermin pada gambar dibawah:

Tabel 1. Daftar negara yang memiliki pasar Ritel Teraktif

\begin{tabular}{l|l|l}
\hline No & Nama Negara & Skor \\
\hline 1 & India & 71,7 \\
\hline 2 & Tiongkok & 70,4 \\
\hline 3 & Malaysia & 60,9 \\
\hline 4 & Turki & 59,8 \\
\hline 5 & Uni Emirat Arab & 59,4 \\
\hline 6 & Vietnam & 56,1 \\
\hline 7 & Maroko & 56,1 \\
\hline 8 & Indonesia & 55,9 \\
\hline 9 & Peru & 54 \\
\hline 10 & Columbia & 53,6 \\
\hline
\end{tabular}

Sumber : A.T. Kearney, 2019

Saat ini di kota Palembang, jumlah gerai minimarket terbanyak masih dikuasai oleh Indomaret dan Alfamart. Bahkan PT Sumber Alfaria Trijaya Tbk (Alfamart) telah merambah toko ritel onlineyaitu Alfamidi bagi masyarakat di kota Palembang. Alfamidi merupakan toko ritel virtual 3D pertama di Indonesia yang memungkinkan semua masyarakat bis amemmiliki toko virtual mereka sendiri.

Indomaret dan Alfamart masih terlihat ekspansif hingga pertengahan tahun ini. Ini tercermin dari data Nielsen Retail Audit yang menunjukkan jumlah gerai Indomaret pada Juni 2018 bertambah 300 unit menjadi 15.526 gerai dari posisi Januari. Demikian pula Alfamart meningkat 32 unit menjadi 13.522 gerai dan Alfamidi bertambah 59 unit menjadi 1.478 gerai dari posisi awal tahun. Jumlah gerai Alfamart, Indomaret, serta Alfamidi di Indonesia dapat dilihat pada gambar berikut:

Tabel 2. Jumlah Gerai Alfamart, Alfamidi dan Indomaret (Jan-Jun 2018)

\begin{tabular}{c|c|c}
\hline No & Nama Minimarket & Jumlah Gerai \\
\hline 1 & Indomaret & 15.526 \\
\hline 2 & Alfamart & 13.522 \\
\hline 3 & Alfamidi & 1.478 \\
\hline
\end{tabular}

Sumber : PT Sumber Alfaria Trijaya Tbk (AMRT), 2018

Bertambahnya jumlah gerai retail modern di Palembang, pengusaha mulai melirik bisnis yang tengah naik daun, sehingga seiring bertambahnya jumlah gerai mengisyaratkan pertambahan jumlah tenaga kerja yang dibutuhkan untuk melakukan kegiatan operasional di tiap gerai baru yang akan dibuka. Namun dengan semakin banyaknya jumlah karyawan yang dibutuhkan maka kesempatan 
promosi yang dihadirkan untuk para karyawan tersebut semakin kecil, sehingga sering kali terjadi career plateau dimana suatu kondisi karir individu yang berhenti pada satu titik yang dialami oleh individu tertentu baik secara terstruktur maupun tidak, padahal pengembangan karir adalah sesuatu yang sangat penting bagi karyawan dan dapat meningkatkan kepuasan kerja karyawan.

Banyaknya gerai minimarket di kota Palembang, dan banyaknya sumber daya manusia yang ada dalam mengisi kekosongan jabatan yang ada, maka kesempatan pengembangan karir sangat kecil bagi karyawan di gerai minimarket di Kota Palembang. Semakin sedikitnya kesempatan promosi maka dapat menjadi salah satu pemicu ketidakpuasan karyawan dengan pekerjaannya.

Berdasarkan latar belakang diatas peneliti tertarik untuk melakukan penelitian peran career plateau terhadap kepuasan kerja karyawan gerai minimarket di kota Palembang.

\section{TINJAUAN PUSTAKA}

\subsection{Career Plateau}

Menurut Allen at al (dalam Shakila Devi :2019), "titik kemandegan dalam karir (career plateau) didefinisikan sebagai suatu titik dalam suatu karir dimana kemungkinan tambahan promosi secara hierarkis sangat rendah". career plateau munvul ketika seorang karyawan berada pada suatu posisi atau jabatan yang kesempatan promosinya sangat kecil bahkan mungkin tidak memiliki kesempatan untuk meningkatkan posisi atau jabatannya.

Career plateau dapat dilihat dari berbagai sisi, seperti secara subjektif dan objektif. Secara subjektif career plateau dilihat saat dimana karyawan telah menerima dan bereaksi bahwa karirnya tidak dapat meningkat, sednagkan secara objektif dapat dilihat dari berapa lama karyawan tersebut berada di suatu posisi atau jabatan dan karyawan tersebut telah melebihi waktu yang ditetapkan untuk seseorang memiliki kesempatakan promosi jabatan (terlalu lama berada dalam suatu posisi atau jabatan). Menurut Allen (dalam Shakila Devi :2019), "penilaian career plateau secara subyektif merupakan persepsi seseorang mengenai karirnya di masa yang akan datang dirasa terbatas atau kecil sekali kemungkinannya untuk dipromosikan”. Jika ini sering terjadi pada suatu organisasi, maka akan berakibat pada kinerja pegawai dan rendahnya daya saing organisasi. Faktor finansial seperti 
gaji/upah sangat mempengaruhi kinerja pegawai. Hasibuan (2012:118), menyatakan bahwa "tujuan seseorang bekerja adalah untuk memperbaiki taraf hidup yang didapat dari imbalan atas hasil kerjanya berupa upah atau gaji”. Dengan demikian jika hasil yang didapat tidak sesuai dengan pekerjaan yang dilakukan maka akan menimbulkan suatu kesenjangan antara pegawai atau karyawan terhadap perusahaan.

Terdapat banyak penyebab dari seseorang dalam meniti karirnya mengalami career plateau (kemandegan karir) ada berbagai macam. Menurut Allen (dalam Shakila Devi :2019), ada tiga indikator career plateau, yaitu sebagai berikut.

1. Faktor demografi

Faktor demografi seperti usia, tingkat pendidikan dan status perkawinan dan jenis kelamin dapat menentukan career plateau seseorang karyawan. Karyawan dengan rentang usia yang masih produktif serta memiliki pendidikan tinggi maka seharusnya career plateau kecil. Hal ini terjadi karena pada usia produktif seharusnya karyawan masih memiliki kesmepatan untuk melakukan pengembangan diri untuk dapat meningkatkan skill dan ability untuk dapat menghindari career plateau.

Namun berbeda dengan karyawan perempuan dengan status perkawinan menikah career palteau akan semakin besar, hal ini terkait dengan budaya yang ada bahwa perempuan yang sudah menikah memiliki tugas utama dalam rumah tangga mengurus keluarga, selain itu jabatan yang lebih tinggi dari kepala keluarga kadangkala menjadi pemicu berbagai penyebab perceraian, sehingga karyawan perempuan dengan status telah menikah memilki kesempatarn career plateau yang tinggi.

2. Faktor orientasi personal

Faktor personal seperti keterlibatan kerja, keinginan untuk belajar, dan eksplorasi karir. Keterlibatan kerja berhubungan dengan pembelajaran dan pengembangan diri. Keterlibatan kerja akan meningkatkan hasil yang diraih berupa gaji atau upah sehingga pekerja lebih termotivasi, lebih produktif, dan berkeinginan untuk belajar lagi. Hal ini akan menjadikan seseorang berpartisipasi dalam pengembangan diri serta termotivasi 
Published online in http://e-journal.uniflor.ac.id/index.php/analisis

untuk bereksplorasi karir untuk meningkatkan keterampilan. Dengan demikian semakin tinggi keterlibatan kerja, keinginan untuk belajar, dan eksplorasi karir maka akan semakin kecil career plateau yang dialaminya.

3. Faktor dukungan sosial seperti dukungan atasan.

Faktor dukungan sosial seperti dukungan atasan juga membantu pegawai. Apabila pegawai tidak meyakini jika mereka mendapat dukungan dari atasan maka mereka tidak bisa untuk naik ke jenjang yang lebih tinggi dan mereka akan merasa pekerjaannya tidak bermanfaat. Dengan demikian semakin tinggi dukungan atasan maka akan semakin kecil career plateau.

\subsection{Job Satisfaction}

Job Satisfaction dan sikap umum terhadap pekerjaan seorang yang menunjukan perbedaan anatara jumlah penghargaan yang diterima dengan yang seharusnya diterima. Kepuasaaan kerja adalah sikap positif atau negatif yang dilakukan individu terhadap pekerjaan. Kepuasaan kerja adalah pemikiran, perasaan, dan kecenderungan tindakan seseorang yang meruapakan sebagaian dari pekerjaan tersebut. Kepusaan kerja dalah respon affetive atau emosional terhadap berbagai segi pekerjaan. (Sinambela, 2012).

Kepuasaan kerja adalah suatu perasaan yang menyokong atau tidak menyokong diri pegawai yang berhubungan dengan pekerjaannya maupun dengan kondisi dirinya (Sinambela, 2012).

Robbins dan Judge (2009:119), menyatakan ada lima faktor kepuasan kerja yaitu:

1. Kepuasan terhadap Pekerjaan

Kepuasan ini tercapai bilamana pekerjaan seorang pegawai sesuai dengan minat dan kemampuan pegawai itu sendiri.

2. Kepuasan terhadap Imbalan

Dimana pegawai merasa gaji atau upah yang diterimanya sesuai dengan beban kerjanya dan seimbang dengan pegawai lain yang bekerja di organisasi itu. 
Published online in http://e-journal.uniflor.ac.id/index.php/analisis

3. Kepuasan terhadap Supervisi Atasan

Pegawai merasa memiliki atasan yang mampu memberikan bantuan teknis dan motivasi.

4. Kepuasan terhadap Rekan Kerja

Pegawai merasa puas terhadap rekan-rekan kerjanya yang mampu memberikan bantuan teknis dan dorongan sosial.

5. Kesempatan Promosi

Kesempatan untuk meningkatkan posisi jabatan pada struktur organisasi.

Penelitian yang dilakukan oleh Wickramasinghe dan Jayaweera (2010) memisahkan career plateau menjadi hierarchical plateau dan job content plateau untuk diuji pengaruhnya terhadap kepuasan kerja. Hasil studi tersebut menunjukkan bahwa hierarchical plateau dan job content plateau terbukti tidak berpengaruh terhadap kepuasan kerja. Demikian pula dengan penelitian yang dilakukan oleh Wulani (2006) menunjukkan bahwa career plateau tidak terbukti berpengaruh terhadap job satisfaction. Sedangkan studi Wulani, Lindawati, dan Suhartatik (2008) yang membagi careerplateu menjadi job content plateau dan hierarchical plateau diuji pengaruhnya terhadap kepuasan kerja. Hasil penelitian tersebut menunjukkan bahwa job content plateau terbukti berpengaruh negatif signifikan terhadap kepuasan kerja sedangkan hierarchical plateau tidak terbukti berpengaruh terhadap kepuasan kerja. Studi Tremblay, Roger, dan Toulouse (1995) juga membuktikan bahwa subjective plateau terbukti berpengaruh negatif signifikan terhadap kepuasan kerja. Demikian pula dengan studi yang dilakukan oleh Lee (2002) menunjukkan bahwa career plateau terbukti berpengaruh negatif dan signifikan terhadap kepuasan kerja. Chang (2003) mengkaitkan career plateau dengan sejumlah dampak negatif yang salah satunya adalah kepuasan kerja. 
Published online in http://e-journal.uniflor.ac.id/index.php/analisis

\subsection{Model Penelitian}

Berikut gambar model penelitian pada penelitian ini:

Gambar 1. Model penelitian

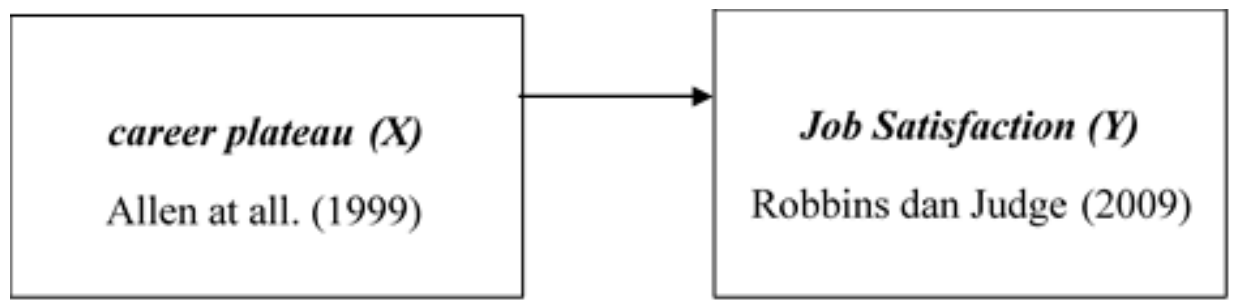

Hipotesis :

career plateau berpengaruh negatif terhadap job satisfaction.

\section{METODE PENELITIAN}

\subsection{Variabel Penelitian}

Pada penelitian ini variabel yang digunakan dua jenis variabel yaitu variabel independen (bebas), dan variabel dependen (terikat). Variabel independen dalam penelitian ini adalah pelatihan Career Plateau. Variabel dependen dalam penelitian ini adalah Job Satisfaction. Teknik pengumpulan data yang dipergunakan dalam penelitian ini adalah survey. Data yang digunakan dalam penelitian ini terdiri dari data primer dan data sekunder. Data primer merupakan sumber data penelitian yang diperoleh secara langsung dari sumber asli atau tanpa melalui media perantara (J. Supranto, 2005). Data sekunder berupa sumber pustaka yang dapat mendukung penulisan penelitian serta diperoleh dari literatur yang relevan dari permasalahan, sebagai dasar pemahaman terhadap objek penelitian dan untuk menganalisisnya secara tepat. 


\subsection{Populasi, Sampel dan Teknik Sampling}

Dalam penelitian ini yang menjadi populasi adalah karyawan gerai minimarket di kota Palembang dalam hal ini ruang lingkup dibatasi hanya karyawan Alfamart dan Indomaret. Teknik pengambilan sampel adalah dengan metode nonprobability sampling yaitu dengan convenience sampling. Peneliti memilih metode convenience sampling didasarkan pada kemudahan mendapatkannya. Sampel diambil karena sampel berada ditempat dan waktu yang tepat (Ferdinand, 2006).

Roscoe dalam Sekaran (2006) mengusulkan aturan untuk menentukan ukuran sampel, ukuran sampel lebih dari 30 dan kurang dari 500 adalah tepat untuk kebanyakan penelitian. Sampel yang digunakan pada penelitian ini adalah 150 orang, mengingat kemampuan peneliti dan kemudahan pengambilan sampel.

\subsection{Uji Kualitas Data}

1. Uji Reliabilitas

Pengukuran reliabilitas dalam penelitian ini dilakukan dengan cara one shot atau pengukuran sekali saja. Disini pengukuran hanya sekali dan kemudian hasilnya dibandingkan dengan pertanyaan lain atau mengukur reliabilitas dengan uji statistik Cronbach Alpha (a). Suatu variabel dikatakan reliable jika nilai Cronbach Alpha (a) $>0,6$.

Tabel 3. Hasil Uji Reliabilitas

\begin{tabular}{|l|c|l|}
\hline Variabel / Indikator & Alpha & Keterangan \\
\hline Career Plateau & 0,748 & Reliabel \\
\hline Kepuasan Kerja & 0,840 & Reliabel \\
\hline
\end{tabular}

2. Uji Validitas

Dalam penelitian ini menggunakan content validity yang dapat menggambarkan kesesuaian sebuah pengukuran data dengan apa yang diukur (Ferdinand, 2006). Jika 
JURNAL ILMIAH FAKULTAS EKONOMI UNIVERSITAS FLORES

VOL. 11 NO. 1 EDISI MARET TAHUN 2021

P. $93-113$

ISSN 1907-5189

e-ISSN 2722-6328

Published online in http://e-journal.uniflor.ac.id/index.php/analisis

suatu indikator mempunyai korelasi antara skor masing-masing indikator terhadap skor totalnya (skor variabel konstruk) maka dikatakan indikator tersebut valid.

Tabel 4. Hasil Uji Validitas Career Plateau

\begin{tabular}{l|l|c|c|c}
\hline No & Pernyataan & R Hitung & R Tabel & Keterangan \\
\hline 1. & $\begin{array}{l}\text { Kesempatan promosi yang diberikan tidak didasarkan } \\
\text { pada usia karyawan saat ini. }\end{array}$ & 0,642 & 0,1603 & Valid \\
\hline 2. & $\begin{array}{l}\text { Tingkat pendidikan tidak mempengaruhi kesempatan } \\
\text { promosi pada perusahaan saya. }\end{array}$ & 0,486 & 0,1603 & Valid \\
\hline 3 & $\begin{array}{l}\text { Kesempatan promosi tidak memandang status } \\
\text { perkawinan karyawan (single atau menikah) }\end{array}$ & 0,394 & 0,1603 & Valid \\
\hline 4 & $\begin{array}{l}\text { Setiap orang diberikan kesempatan yang sama dalam } \\
\text { setiap kesempatan promosi jabatan baik pria maupun } \\
\text { wanita }\end{array}$ & 0,518 & 0,1603 & Valid \\
\hline 5. & $\begin{array}{l}\text { Saya memiliki komitmen yang tinggi terhadap } \\
\text { pekerjaan, profesi saya saat ini }\end{array}$ & 0,861 & 0,1603 & Valid \\
\hline 6. & $\begin{array}{l}\text { Saya memiliki motivasi yang tinggi serta kepedulian } \\
\text { yang tertinggi terhadap pekerjaan dan perusahaan }\end{array}$ & 0,634 & 0,1603 & Valid \\
\hline 7. & $\begin{array}{l}\text { Saya selalu berusaha mengembangkan diri dengan } \\
\text { melakukan pembelajaran secara berkelanjutan }\end{array}$ & 0,897 & 0,1603 & Valid \\
\hline 8 & $\begin{array}{l}\text { Saya selalu meneliti apa yang akan saya lakukan } \\
\text { terhadap perkembangan karir saya }\end{array}$ & 0,705 & 0,1603 & Valid \\
\hline 9 & $\begin{array}{l}\text { Atasan saya selalu memberikan motivasi kepada saya } \\
\text { alam menjalankan pekerjaan. }\end{array}$ & 0,845 & 0,1603 & Valid \\
\hline 10 & $\begin{array}{l}\text { Atasan selalu memberikan informasi mengenai } \\
\text { kesempatan promosi yang tersedia di perusahan }\end{array}$ & 0,765 & 0,1603 & Valid \\
\hline 11 & $\begin{array}{l}\text { Saya dan rekan kerja selalu saling mendorong dan } \\
\text { berbagi informasi untuk kemajuan karir masing- } \\
\text { masing }\end{array}$ & 0,685 & 0,1603 & Valid \\
\hline
\end{tabular}

Tabel 5. Hasil Uji Validitas Job Satisfaction 
JURNAL ILMIAH FAKULTAS EKONOMI UNIVERSITAS FLORES

VOL. 11 NO. 1 EDISI MARET TAHUN 2021

P. $93-113$

ISSN 1907-5189

e-ISSN 2722-6328

Published online in http://e-journal.uniflor.ac.id/index.php/analisis

\begin{tabular}{|c|c|c|c|c|}
\hline No & PERTANYAAN & R Hitung & R Tabel & Keterangan \\
\hline 1 & $\begin{array}{l}\text { Saya sudah merasa puas dengan pekerjaan yang dijalani } \\
\text { saat ini }\end{array}$ & 0,894 & 0,1603 & Valid \\
\hline 2 & $\begin{array}{l}\text { Saya merasa puas dengan beban pekerjaan yang } \\
\text { terkadang dilimpahkan kepada anda }\end{array}$ & 0,343 & 0,1603 & Valid \\
\hline 3 & $\begin{array}{l}\text { Pekerjaan yang saya lakukan saat ini sudah sesuai } \\
\text { dengan latar belakang pendidikan, kemampuan, dan } \\
\text { keahlian saya }\end{array}$ & 0,556 & 0,1603 & Valid \\
\hline 4 & $\begin{array}{l}\text { Saya sudah merasa puas dengan penghasilan yang } \\
\text { diberikan oleh pihak perusahaan }\end{array}$ & 0,604 & 0,1603 & Valid \\
\hline 5 & $\begin{array}{l}\text { Gaji yang saya terima tidak sesuai dengan tingkat } \\
\text { pendidikan saya }\end{array}$ & 0,639 & 0,1603 & Valid \\
\hline 6 & Besar dan jenis tunjangan yang diterima sudah sesuai & 0,688 & 0,1603 & Valid \\
\hline 7 & Bimbingan yang diberikan oleh atasan saya jelas & 0,374 & 0,1603 & Valid \\
\hline 8 & $\begin{array}{l}\text { Pada saat bekerja, atasan saya bersedia memberikan } \\
\text { bimbingan bila saya tidak memahami pekerjaan yang } \\
\text { ditugaskan }\end{array}$ & 0,612 & 0,1603 & Valid \\
\hline 9 & Hubungan dengan rekan kerja terjalin dengan baik & 0,317 & 0,1603 & Valid \\
\hline 10 & $\begin{array}{l}\text { Bilamana dibutuhkan rekan kerja memberikan bantuan } \\
\text { langsung dalam upaya untuk menyelesaikan pekerjaan } \\
\text { tepat pada waktunya }\end{array}$ & 0,494 & 0,1603 & Valid \\
\hline 11 & $\begin{array}{l}\text { Kebijakan promosi (kenaikan pangkat, atau jabatan) di } \\
\text { perusahaan ini belum sesuai }\end{array}$ & 0,402 & 0,1603 & Valid \\
\hline 12 & $\begin{array}{l}\text { Promosi karyawan di perusahaan ini dilakukan secara } \\
\text { obyektif }\end{array}$ & 0,557 & 0,1603 & Valid \\
\hline
\end{tabular}

\subsection{Uji Asumsi Klasik}

1. Uji Heteroskedastisitas

Uji heteroskedastisitas bertujuan menguji apakah dalam model regresi terjadi ketidaksmaan varian dari residual satu pengamatan dengan pengamatan lain. Jika varian dari residual satu pengamatan dengan pengamatan lain tetap, maka disebut homoskedestisitas dan jika berbeda disebut heteroskedastisitas.

2. Uji Normalitas

Uji ini bertujuan untuk menguji apakah dalam model regresi, variabel pengganggu atau residual memiliki distribusi normal. Kita dapat melihatnya dari normal probability plot yang membandingkan distribusi kumulatif dengan distribusi normal. Distribusi normal membentuk suatu garis lurus diagonal, dan ploting data residual akan dibandingkan dengan garis diagonalnya. Jika distribusi data normal, maka garis 
Published online in http://e-journal.uniflor.ac.id/index.php/analisis

yang menggambarkan data sebenarnya akan mengikut garis normalnya (Ghozali, 2005).

\subsection{Analisis Regresi}

Analisis regresi digunakan untuk mengetahui dampak career plateau terhadap job satisfaction karyawan di kota Palembang. Selain itu juga analisis regresi digunakan untuk menguji kebenaran hipotesis yang diajukan dalam penelitian ini, yang modelnya sebagai berikut :

$$
\mathbf{Y}=\mathbf{a}+\mathbf{b x}+\mathbf{e}
$$

Dimana:

$\mathrm{Y}=$ Job Satisfaction

$\mathrm{X}=$ Career Plateau

$\mathrm{b}=$ koefisien regresi

$\mathrm{e}=$ error

\subsection{Pengujian Hipotesis}

Ketepatan fungsi regresi sampel dalam menaksir nilai aktual dapat dinilai dengan godness of fit-nya. Secara statistik setidaknya ini dapat diukur dari nilai koefisien determinasi $\left(\mathrm{R}^{2}\right)$, dan nilai statistik t.

1. Koefisien determinasi $\left(\mathrm{r}^{2}\right)$

Koefisien determinasi $\left(\mathrm{r}^{2}\right.$ ) pada intinya mengukur seberapa jauh kemampuan sebuah model menerangkan variasi variabel dependen. Nilai koefisien determinasi adalah antara nol dan satu. Nilai $\mathrm{r}^{2}$ yang kecil berarti kemampuan variabel-variabel independen dalam menjelaskan variabel dependen sangat terbatas. Nilai yang mendekati satu berarti variabel- variabel independen memberikan hampir semua informasi yang dibutuhkan untuk memprediksi variasi variabel dependen (Ghozali, 2005). 


\section{Uji Parsial (Uji t)}

Untuk menentukan koefisien spesifik yang mana yang tidak sama dengan nol, uji tambahan diperlukan yaitu dengan menggunakan uji t. Uji statistik t pada dasarnya menunjukkan seberapa jauh pengaruh satu variabel independen secara individual dalam menerangkan variasi variabel dependen (Ghozali, 2005). Sigifikansi koefisien parsial ini memiliki distribusi t dengan derajat kebebasan n-k1 , dan signifikan pada $\alpha=0,05$.

\section{HASIL DAN PEMBAHASAN}

Penelitian ini mengambil sampel karyawan minimarket di Kota Palembang, jumlah sampel sebanyak 150 orang. Diperoleh sebanyak 150 instrumen berupa kuesioner dapat terkumpul dari kuesioner yang didistribusikan. Dari kuesioner yang telah diisi oleh responden didapat data identitas responden. Adapun penyajian data mengenai identitas responden untuk memberikan gambaran pada diri responden.

Tabel 6. Demografi Responden

\begin{tabular}{|c|c|c|c|}
\hline Variable & Kategori & Frekuensi & $\%$ \\
\hline \multirow[t]{2}{*}{ Jenis Kelamin } & Laki-laki & 63 & 42 \\
\hline & Perempuan & 87 & 58 \\
\hline \multirow[t]{5}{*}{ Usia } & $18-23$ & 91 & 60,7 \\
\hline & $24-29$ & 54 & 37,3 \\
\hline & $30-35$ & 3 & 2,0 \\
\hline & $36-41$ & 0 & 0 \\
\hline & $>41$ & 0 & 0 \\
\hline \multirow[t]{5}{*}{ Pendidikan } & SMA/SMK & 98 & 65,3 \\
\hline & Diploma & 7 & 4,7 \\
\hline & $\mathrm{S} 1$ & 45 & 30,0 \\
\hline & $\mathrm{S} 2$ & 0 & 0 \\
\hline & S3 & 0 & 0 \\
\hline \multirow[t]{2}{*}{ Status Perkawinan } & Belum Menikah & 117 & 78,0 \\
\hline & Menikah & 33 & 22 \\
\hline \multirow[t]{3}{*}{ Status Pekerjaan } & Outsourching & 112 & 74,7 \\
\hline & Kontrak & 33 & 22 \\
\hline & Tetap & 5 & 3,3 \\
\hline
\end{tabular}

Sumber : Data Primer (2020)

Dari hasil penelitian mengenai demografi responden menyatakan bahwa career plateau dapat lebih tinggi terjadi pada perempuan karena banyak persepsi di masyarakat 
bahwa perempuan tidak boleh memiliki jabatan yang lebih tinggi dari pada laki-laki, sehingga hal ini membuat kemandegan karir yang terjadi pada perempuan akan lebih tinggi dibandingkan dengan laki-laki. Karyawan minimarket di Palembang sebagian besar masih pada usia produktif. Hal ini menunjukkan pegawai mampu untuk meningkatkan lebih aktif dan memiliki motivasi dan keinginan belajar yang tinggi, sehingga seharusnya career plateau pada usia produktif adalah rendah. Sebagian besar karyawan yang bekerja di minimarket di kota Palembang berpendidikan tinggi, sehingga diharapkan dapat memberikan sumbangsih pemikiran dan produktitas yang baik bagi organisasi sehingga tingkat career plateau yang terjadi pun diharapkan dapat rendah. karyawan minimarket dikota palembang sebagian besar adalah belum menikah, seharusnya mereka dapat fokus terhadap pekerjaan dan karir dan tingkat career plateau rendah. Status karyawan yang tertinggi adalah karyawan outsourcing atau karyawan yang dipekerjakan oleh pihak ketiga yaitu 112 orang atau 74,7, hal inilah yang membuat kemandegan karir terjadi pada para karyawan di minimarket kota palembang, kesempatan untuk mendapatkan karir yang lebih baik sangat kecil bagi para karyawan, sedangkan ada 33 orang atau 22 persen dengan status sebagai karyawan kontrak, hal ini merupakan sedikit kemajuan bagi karyawan, karena akan ada kesempatan bagi karyawan kontrak untuk dapat meningkatkan status sebagai karyawan tetap, namun tidak setiap karyawan kontrak akan menjadi karyawan tetap, mereka harus melewati proses seleksi terlebih dahulu.

Analisis ini dilakukan untuk mendapatkan gambaran deskriptif mengenai responden penelitian ini, khususnya variabel-variabel penelitian yang digunakan dalam penelitian ini. Dalam penelitian ini digunakan teknik skoring yaitu nilai minimal 1 dan nilai maksimal 5 . Maka perhitungan indeks jawaban responden sebagai berikut : 
Published online in http://e-journal.uniflor.ac.id/index.php/analisis

Tabel 7. Tabel Tanggapan Responden Variabel Career Plateau

\begin{tabular}{|c|c|c|c|c|c|c|c|}
\hline \multicolumn{8}{|c|}{ Kemampuan dan Kesediaan Perusahaan } \\
\hline & Pernyataan & $\begin{array}{l}\text { Sangat } \\
\text { Setuju }\end{array}$ & Setuju & Netral & $\begin{array}{l}\text { Tidak } \\
\text { Setuju }\end{array}$ & $\begin{array}{l}\text { Sangat } \\
\text { Tidak } \\
\text { Setuju }\end{array}$ & $\begin{array}{l}\text { Rata- } \\
\text { Rata }\end{array}$ \\
\hline \multicolumn{8}{|c|}{ Demografi } \\
\hline 1 & $\begin{array}{lll}\text { Kesempatan promosi } & \text { yang } \\
\text { diberikan tidak didasarkan } & \text { pada } \\
\text { usia karyawan saat ini. } & \\
\end{array}$ & 118 & 18 & 14 & & & 4,69 \\
\hline 2 & $\begin{array}{l}\text { Tingkat pendidikan tidak } \\
\text { mempengaruhi kesempatan promosi } \\
\text { pada perusahaan saya. }\end{array}$ & 78 & 65 & 7 & & & 4,47 \\
\hline 3 & $\begin{array}{l}\text { Kesempatan promosi tidak } \\
\text { memandang status perkawinan } \\
\text { karyawan (single atau menikah) }\end{array}$ & 87 & 49 & 14 & & & 4,48 \\
\hline 4 & $\begin{array}{l}\text { Setiap orang diberikan kesempatan } \\
\text { yang sama dalam setiap kesempatan } \\
\text { promosi jabatan baik pria maupun } \\
\text { wanita }\end{array}$ & 80 & 49 & 21 & & & 4,39 \\
\hline \multicolumn{8}{|c|}{ Personal } \\
\hline 5 & $\begin{array}{l}\text { Saya memiliki komitmen yang } \\
\text { tinggi terhadap pekerjaan, profesi } \\
\text { saya saat ini }\end{array}$ & 74 & 65 & 11 & & & 4,42 \\
\hline 6 & $\begin{array}{l}\text { Saya memiliki motivasi yang tinggi } \\
\text { serta kepedulian yang tertinggi } \\
\text { terhadap pekerjaan dan perusahaan }\end{array}$ & 90 & 53 & 7 & & & 4,55 \\
\hline 7 & $\begin{array}{lr}\text { Saya selalu } & \text { berusaha } \\
\text { mengembangkan diri } & \text { dengan } \\
\text { melakukan pembelajaran } & \text { secara } \\
\text { berkelanjutan } & \\
\end{array}$ & 81 & 44 & 25 & & & 4,37 \\
\hline 8 & \begin{tabular}{|lr|}
\multicolumn{3}{|l}{ Saya selalu meneliti apa yang akan } \\
saya lakukan & terhadap \\
perkembangan karir saya & \\
\end{tabular} & 60 & 75 & 15 & & & 4,30 \\
\hline \multicolumn{8}{|c|}{ Faktor Lingkungan } \\
\hline 9 & $\begin{array}{l}\text { Atasan saya selalu memberikan } \\
\text { motivasi kepada saya dalam } \\
\text { menjalankan pekerjaan. }\end{array}$ & 89 & 38 & 23 & & & 4,44 \\
\hline 10 & 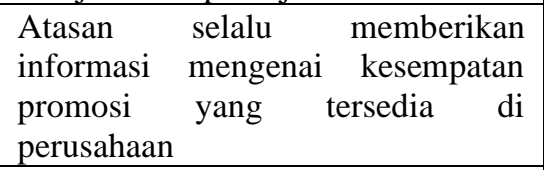 & 88 & 52 & 10 & & & 4,52 \\
\hline 11 & $\begin{array}{l}\text { Saya dan rekan kerja selalu saling } \\
\text { mendorong dan berbagi informasi } \\
\text { untuk kemajuan karir masing- } \\
\text { masing }\end{array}$ & 63 & 45 & 42 & & & 4,14 \\
\hline
\end{tabular}


Published online in http://e-journal.uniflor.ac.id/index.php/analisis

Variabel kepuasan kerja dalam penelitian ini diukur melalui lima indikator. Hasil tanggapan terhadap variabel kepuasan kerja dapat dijelaskan sebagai berikut:

Tabel 8. Tabel Tanggapan Responden Variabel Job Satisfaction

\begin{tabular}{|c|c|c|c|c|c|c|c|}
\hline \multicolumn{8}{|c|}{ Arti penting aspek kerja } \\
\hline No & Pernyataan & $\begin{array}{l}\text { Sangat } \\
\text { Setuju }\end{array}$ & Setuju & Netral & $\begin{array}{l}\text { Tidak } \\
\text { Setuju }\end{array}$ & $\begin{array}{l}\text { Sangat } \\
\text { Tidak } \\
\text { Setuju }\end{array}$ & $\begin{array}{l}\text { Rata- } \\
\text { Rata }\end{array}$ \\
\hline \multicolumn{8}{|c|}{ Kepuasan Terhadap Pekerjaan } \\
\hline 1 & $\begin{array}{l}\text { Saya sudah merasa puas } \\
\text { dengan pekerjaan yang } \\
\text { dijalani saat ini }\end{array}$ & 62 & 49 & 39 & & & 4,15 \\
\hline 2 & $\begin{array}{l}\text { Saya merasa puas dengan } \\
\text { beban pekerjaan yang } \\
\text { terkadang dilimpahkan } \\
\text { kepada anda }\end{array}$ & 60 & 60 & 30 & & & 4,20 \\
\hline 3 & $\begin{array}{l}\text { Pekerjaan yang saya } \\
\text { lakukan saat ini sudah } \\
\text { sesuai dengan latar } \\
\text { belakang pendidikan, } \\
\text { kemampuan, dan keahlian } \\
\text { saya }\end{array}$ & 71 & 50 & 29 & & & 4,28 \\
\hline \multicolumn{8}{|c|}{ Kepuasan Terhadap Imbalan } \\
\hline 4 & $\begin{array}{l}\text { Saya sudah merasa puas } \\
\text { dengan penghasilan yang } \\
\text { diberikan oleh pihak } \\
\text { perusahaan }\end{array}$ & 58 & 52 & 58 & & & 4,12 \\
\hline 5 & $\begin{array}{l}\text { Gaji yang saya terima tidak } \\
\text { sesuai dengan tingkat } \\
\text { pendidikan saya }\end{array}$ & 54 & 67 & 29 & & & 4,16 \\
\hline 6 & $\begin{array}{l}\text { Besar dan jenis tunjangan } \\
\text { yang diterima sudah sesuai }\end{array}$ & 75 & 51 & 24 & & & 4,34 \\
\hline \multicolumn{8}{|c|}{ Kepuasan Terhadap Supervisi Atasan } \\
\hline 7 & $\begin{array}{l}\text { Bimbingan yang diberikan } \\
\text { oleh atasan saya jelas }\end{array}$ & 29 & 65 & 56 & & & 3,82 \\
\hline 8 & $\begin{array}{l}\text { Pada saat bekerja, atasan } \\
\text { saya bersedia memberikan } \\
\text { bimbingan bila saya tidak } \\
\text { memahami pekerjaan yang } \\
\text { ditugaskan }\end{array}$ & 55 & 66 & 29 & & & 4,17 \\
\hline \multicolumn{8}{|c|}{ Kepuasan Terhadap Rekan Kerja } \\
\hline 9 & $\begin{array}{l}\text { Hubungan dengan rekan } \\
\text { kerja terjalin dengan baik }\end{array}$ & 84 & 45 & 21 & & & 4,42 \\
\hline
\end{tabular}


Published online in http://e-journal.uniflor.ac.id/index.php/analisis

\section{Uji Asumsi Klasik}

\section{a) Uji Normalitas}

Uji Normalitas bertujuan untuk menguji apakah dalam model regresi, variabel pengganggu atau residual memiliki distribusi normal. Hasilnya menunjukan bawa nilai signifikansi (Sig.) sebesar 0.084 lebih besar dari 0.05 . yang artinya data penelitian ini berdistribusi normal.

Tabel 9. Uji Normalitas

\begin{tabular}{l|r}
\multicolumn{2}{c}{ One-Sample Kolmogorov-Smirnov Test } \\
& $\begin{array}{c}\text { Unstandardized } \\
\text { Residual }\end{array}$ \\
\hline Asymp. Sig. (2-tailed) & $.084^{\mathrm{c}}$ \\
\hline
\end{tabular}

\section{b) Uji Heterokedestisitas}

Uji Heterokedestisitas bertujuan menguji apakah dalam model regresi terjadi ketidaksamaan variance dari residual satu pengamatan ke pengamatan lain. Hasil menunjukan bahwa variabel career plateau tidak ada gejala heterokedetisitas karena nilai signifikansi $>0.05$.

Tabel 10. Hasil Uji Heterokedestisitas

\begin{tabular}{l|c}
\hline & \\
Variabel & Nilai Sig. \\
\hline Career Plateau & 0,058
\end{tabular}

\section{c) Analisis Regresi Linier}

Analisis Regresi adalah studi mengenai ketergantungan variabel dependen (terikat) dengan satu atau lebih variabel independen (bebas), dengan tujuan untuk mengestimasi dan/atau memprediksi rata-rata populasi atau nilai rata-rata variabel dependen berdasarkan nilai variabel independen yang diketahui (Gujarai, 2003).

Adapun hasil analisis regresi linier berganda pada penelitian ini dapat dilihat pada tabel berikut: 
JURNAL ILMIAH FAKULTAS EKONOMI UNIVERSITAS FLORES

VOL. 11 NO. 1 EDISI MARET TAHUN 2021

P. $93-113$

ISSN 1907-5189

e-ISSN 2722-6328

Published online in http://e-journal.uniflor.ac.id/index.php/analisis

Tabel 11. Hasil Pengujian Regresi Linier Berganda

\begin{tabular}{l|l|l|l|l}
\hline Kepuasan Kerja $=\mathbf{2 1 , 0 2 4 + 0 , 6 0 0 X + e}$ & Hypothetical & information \\
\hline $\begin{array}{l}\text { Independen } \\
\text { Variable }\end{array}$ & Coefficient & Sig. & & \\
\hline Constant & 21,024 & & Positif & H1 ditolak \\
\hline Career Plateau & 0,600 & 0,000 & & \\
\hline
\end{tabular}

Koefisien regresi $\mathrm{X}$ bernilai positif 0.600 artinya hubungan Kuepuasan kerja dan career plateau adalah positif. Ini mengandung arti bahwa setiap kenaikan career plateau (X) satu satuan maka variabel Kepuasan Kerja (Y) akan naik sebesar 0.600.

\section{d) Koefisien Determinasi}

Koefisien Determinasi (R square) bermakna sebagai sumbangan variabel bebas atau variabel independen $(\mathrm{X})$ terhadap variabel terikat atau variabel dependen $(\mathrm{Y})$, atau dengan kata lain, nilai koefisien determinasi atau $\mathrm{R}$ square ini berguna untuk memprediksi dan melihat seberapa besar kontribusi pbngaruh yang diberikan variabel $\mathrm{X}$ secara simultan terhadap variabel Y.

Tabel 12. Koefisien Determinasi

\begin{tabular}{l|r|r|r|r}
\hline Model & R & R Square & \multicolumn{1}{|c|}{$\begin{array}{c}\text { Adjusted R } \\
\text { Square }\end{array}$} & $\begin{array}{c}\text { Std. Error of } \\
\text { the Estimate }\end{array}$ \\
\hline 1 &, $602^{\mathrm{a}}$ &, 362 &, 358 & 2,16092 \\
\hline
\end{tabular}

Dari tabel 5.6 dapat diketahui bahwa hasil bahwa besarnya nilai adjusted R2 adalah 0.362, hal ini berarti 36,2 \% variasi kepuasan kerja dapat dijelaskan oleh variasi lain dari variabel independen career plateau. Sedangkan sisanya 63,8\% dijelaskan oleh variabel lain diluar model.

\section{e) Pengujian Hipotesis}

Tujuan dari Uji Hipotesis adalah untuk menetapkan suatu dasar sehingga dapat mengumpulkan bukti yang berupa data-data dalam menentukan keputusan apakah menolak atau menerima kebenaran dari pernyataan atau asumsi yang telah dibuat. Uji Hipotesis juga dapat memberikan kepercayaan diri dalam pengambilan keputusan yang bersifat Objektif. Hasil pengujian model dapat dilihat pada tabel dibawah ini: 
Published online in http://e-journal.uniflor.ac.id/index.php/analisis

Tabel 13 Hasil Pengujian Hipotesis

\begin{tabular}{l|c|l|l|l|c}
\hline $\begin{array}{l}\text { Independen } \\
\text { Variable }\end{array}$ & $\begin{array}{l}\text { Nilai T } \\
\text { HItung }\end{array}$ & $\begin{array}{l}\text { Nilai T } \\
\text { Tabel }\end{array}$ & Sig. & $\begin{array}{l}\text { Hypothetical } \\
\text { direction }\end{array}$ & information \\
\hline Career Plateau & 9,172 & 1,976 &, 000 & Positif & H1 ditolak \\
\hline
\end{tabular}

Berdasarkan hasil pengujian hipotesis secara parsial dapat diketahui bahwa variabel $\mathrm{X}$ (career plateau) mempunyai thitung yakni 9,712 dengan $t_{\text {tabel }}=1.976$. Jadi $t_{\text {hitung }}>t_{\text {tabel }}$ dapat disimpulkan bahwa variabel X memiliki kontribusi terhadap Y. Hal ini di dukung dengan nilai signifikansi yang diperoleh yaitu, $000<0.05$, artinya career plateau $(\mathrm{X})$ berpengaruh terhadap Job Satisfaction (Y) arah positif. Sehingga dapat disimpulkan bahwa hipotesis ditolak.

\section{f) Uji T}

Uji t dikenal dengan uji parsial, yaitu untuk menguji bagaimana pengaruh masing-masing variabel bebasnya secara sendiri-sendiri terhadap variabel terikatnya. Uji ini dapat dilakukan dengan mambandingkan $\mathrm{t}$ hitung dengan $\mathrm{t}$ tabel atau dengan melihat kolom signifikansi pada masing-masing t hitung.

Variabel $\mathrm{X}_{1}$ mempunyai thitung yakni 9,172 dengan $\mathrm{t}_{\text {tabel }}=1.976$. Jadi $\mathrm{t}_{\text {hitung }}>\mathrm{t}_{\text {tabel }}$ dapat disimpulkan bahwa variabel X memiliki kontribusi terhadap Y. Hal ini di dukung dengan nilai signifikansi yang diperoleh yaitu $0,000<0.05$, maka dapat disimpulkan bahwa variabel career plateau memiliki pengaruh terhadap job satisfaction.

Berdasarkan hasil pengujian hipotesis secara parsial dapat diketahui bahwa variabel $\mathrm{X}$ (career plateau) mempunyai thitung yakni 9,712 dengan $t_{\text {tabel }}=1.976$. Jadi $t_{\text {hitung }}>t_{\text {tabel }}$ dapat disimpulkan bahwa variabel $\mathrm{X}$ memiliki kontribusi terhadap Y. Hal ini di dukung dengan nilai signifikansi yang diperoleh yaitu, $000<0.05$, artinya career plateau $(\mathrm{X})$ berpengaruh terhadap Kepuasan Kerja (Y) arah positif. Sehingga dapat disimpulkan bahwa hipotesis ditolak. Hal ini mungkin terjadi dikarenakan pada penelitian ini variabel career plateau tidak dipisahkan menjadi Variabel X1 (structural plateauing) dan Variabel X2 ( job content plateauing) sehingga responden kurang memahami mengenai maksud dan tujuan peneliti mengenai pengertian career plateau.

Ketidaksesuaian hasil penelitian ini dengan penelitian sebelumnya dapat terjadi karena 
sampel yang digunakan pada penelitian ini sebagian besar adalah perempuan dengan rentang usia muda dan berstatus belum menikah dengan status kepegawaian adalah outsourcing, sehingga diduga karyawan tidak terlalu perduli dengan kemandegan karir yang terjadi. Umumnya anak muda dengan rentang usia 18 tahun-23 tahun adalah karyawan frash graduate yaitu karyawan muda yang baru pertama kali bekerja, sehingga perkembangan karir bukan menjadi hal yang utama melainkan pengalaman kerja yang diperoleh untuk pertama kalinya.

Hasil uji statistik yang dilakukan pada variabel career plateau dan kepuasan kerja menunjukkan bahwa career plateau terbukti berpengaruh signifikan secara positif terhadap kepuasan kerja. Artinya, jika dalam suatu organisasi terjadi career plateau yang tinggi maka kepuasan kerja karyawan juga akan tinggi. Hal ini tidak sesuai dengan teori yang ada karena perasaan puas atau tidak puas yang dirasakan oleh seorang karyawan terkait dengan kesempatan promosi, pekerjaan yang menarik, tanggung jawab, kondisi kerja, apresiasi, job security, training program, loyalitas personal, gaji dan tunjangan yang baik, rekan kerja, supervisi, lokasi kerja, jam kerja, keinginan untuk menjadi bagian dari perusahaan dan simpati dalam membantu karyawan menyelesaikan masalah. Apabila terdapat salah satu aspek tidak terpenuhi yang di dalam penelitian ini adalah terkait dengan hambatan karir atau career plateau dapat menyebabkan karyawan menjadi tidak puas terhadap pekerjaannya.

\section{KESIMPULAN}

Berdasarkan hasil pengolahan data dan pembahasan terhadap hasil penelitian dapat diambil kesimpulan bahwa variabel career plateau (X) terdapat pengaruh yang signifikan secara positif terhadap variabel Kepuasan Kerja (Y) pada karyawan minimarket di kota Palembang.

Penelitian yang akan datang diharapkan jumlah sampel yang digunakan lebih banyak, serta memisahkan variabel career plateau menjadi 2 sub variabel yaitu structural plateauing dan job content plateauing. Dengan sampel yang relatif lebih banyak maka hasil analisis dari penelitian yang didapatkan akan lebih akurat. Masih perlu dilakukan penelitian pada aspek yang sama untuk mengetahui konsistensi hasil penelitian ini. Sebaiknya menambah faktor - faktor lain yang berpengaruh terhadap kinerja karyawan sehingga penelitian mendatang akan menghasilkan 
penelitian yang lebih lengkap.

\section{REFERENSI}

Allen, T.D., Russell, J.E.A., Poteet, M.L., \& Dobbins, G.H. (1999). Learning and development factors related to perceptions of job content and hierarchical plateauing. Journal of Organizational Behavior, 20, 1113 - 1137.

As'ad, Moh, 2004. Psikologi Industri: Seri ilmu Sumber Daya Manusia, Penerbit Liberty, Yogyakarta.

Bardwick,J. M. (1986). The plateauing trap: How to avoid it in your career. . . and your lqe. New York: American Management Association.

Bambang Supomo dan Nur Indriantoro, 2002, Metodologi Penelitian Bisnis, Cetakan Kedua, Yogyakara; Penerbit BFEE UGM.

Ferdinand, Augusty. 2006. Metode Penelitian Manajemen: Pedoman Penelitian untuk skripsi, Tesis dan Disertai Ilmu Manajemen. Semarang: Universitas Diponegoro.

Ghozali, Imam. 2005. Aplikasi Analisis Multivariate dengan Program SPSS. Badan Penerbit Universitas Diponegoro. Semarang.

Hasibuan, Malayu. 2012. Manajemen Sumber Daya Manusia. Edisi Revisi.Jakarta: PT Bumi Aksara

Jewell, L. N. dan Siegall, M., (1998). Psikologi Industri/Organisasi Modern: Psikologi Penerapan Untuk Memecahkan Berbagai Masalah Di Tempat Kerja, Perusahaan, Industri, Dan Organisasi, ed-2, hal 529. Jakarta: Arcan

Kreitner, Robert dan Angelo Kinicki (2003), Perilaku Organisasi, Penerbit Salemba Empat

Luthans, Fred. 2006. Perilaku Organisasi, (Alih Bahasa V.A Yuwono, dkk), Edisi Bahasa Indonesia, Yogyakarta: ANDI.

Lee, Patrick Chang Boon (2002), Going Beyond career plateau Using Professional Plateau to Account for Work Outcomes, The Journal of Management Development, 22 (5/6).

Rivai, Veithzal. 2011.Manajemen Sumber Daya Manusia Untuk Perusahaan. Jakarta: PT Raja Grafindo Persada

Robbins, Stephen P. dan Timothy A. Judge. 2008. Perilaku Organisasi Edisi ke-12, Jakarta: Salemba Empat.

Sekaran. Uma. 2006. Metode Penelitian Bisnis. Salemba Empat, Jakarta.

Shakila, Devi \& Rabiyathul Basariya. Career Plateu and Dealing Strategies. International Journal of Research in Pharmaceutical and Biomedical Sciences, Vol 6, Iss 1. 2348-1269

Schein,E.H. The Individual, The organization, and the career : A conceptual Scheme. Journal of Applied Behavioral Science.7.1971.401-426.

Sinambela, Lijan Poltak. 2012. Kinerja Pegawai. Graha Ilmu: Yogyakarta.

http://www.rmolsumsel.com/read/2017/01/14/64469/Alfamart-dan-Indomaret-Palembang-MalahKuasai-400-Gerai-

https://databoks.katadata.co.id/datapublish/2018/10/05/gerai-alfamart-dan-indomaret-masih-ekspansi 